Article

\title{
The (Unintended) Consequences of New Labour: Party Leadership vs Party Management in the British Labour Party
}

\author{
Emmanuelle Avril \\ Département du Monde Anglophone, Sorbonne Nouvelle University, 75006 Paris, France; \\ E-Mail: emmanuelle.avril@univ-paris3.fr
}

Submitted: 16 December 2015 | Accepted: 22 March 2016 | Published: 23 June 2016

\begin{abstract}
This article draws from the fields of political science and of organisational studies to explore the short-term and longterm impact of New Labour's party management on the quality of party processes as well as on party reputation. It is based on the long-term ethnographic participant observation of the Labour Party at local and regional levels, as well as national events such as annual conferences. The article starts by identifying the distinctive features of New Labour's party management. It then examines the "unintended consequences" of this brand of party management, showing this model to be mainly self-defeating. The final section provides a general assessment of the impact of New Labour's party management from the perspective of organisational learning and innovation. Overall the article stresses the long-term poisonous effects of this brand of leadership and management on political organisations and on politics in general.
\end{abstract}

\section{Keywords}

Labour Party; leadership; management; New Labour; organisational learning; unintended effects

Issue

This article is part of the issue "New Approaches to Political Leadership", edited by Mark Bennister (Canterbury Christ Church University, UK).

(C) 2016 by the author; licensee Cogitatio (Lisbon, Portugal). This article is licensed under a Creative Commons Attribution 4.0 International License (CC BY).

\section{Introduction}

Although in most models successful leadership is equated with winning and with holding onto office, longevity in power cannot be the only variable used in assessing leadership, especially in a country such as the UK where the Prime Minister is also a party leader and where, as a consequence, there exists a powerful dialectical relationship between internal and external consequences of individual leadership. Therefore, even though there is an impression of immediate success through the historic series of election victories, assessments of Tony Blair's leadership must also include the effects on the long-term electoral prospects of the party, the level of internal democracy, the ability of the party to keep evolving, as well as the attitudes and feelings of members. A complete evaluation of leadership would need to consider the triangle of agency, followers and environment as well as the outcomes re- sulting from the relations between the three. However this article seeks to analyse the issue of political leadership specifically in its interaction with party management, which, according to Buller and James's statecraft model (2012), constitutes one of the five criteria by which to assess leadership. The dimension of individuality and personality cannot be set aside, nor can the context in which the evolution took place. But the decision to take party management as a focal point reflects the fact that, under New Labour, this dimension took centre stage.

The approach, based on the identification of a longterm trend towards increasing organisational convergence between public and private organisations (Avril \& Zumello, 2013), combines analytical tools and concepts borrowed from both the field of political science and that of organisational studies. Pioneer political comparatist Joseph LaPalombara urges political scientists to pay more attention to the concept of "organisa- 
tional learning", which at present draws most of its knowledge from studies of the firm, arguing that "people who see similarities in organisations, in whatever sphere they may be found, are basically correct in their perceptions" (LaPalombara, 2003, p. 575). This trend is reflected in a growing body of literature on toxic/bad/destructive leadership indicating that political scientists are beginning to appropriate tools and concepts previously confined to the business sphere. Thus McAnulla's (2011) analysis of Blair's leadership draws the "toxic triangle" model of destructive leadership from management studies experts Padilla, Hogan and Kaiser (2007), while Tim Heppell (2011) borrows from business academic Lipman-Blumen (2004) to test the applicability of the concept of "toxicity" to the study of five controversial political leaders, including Tony Blair. This coincides with the recent rise of critical approaches to leadership which emphasize destructive leaders' behaviour, underlining the destructive dimension of charismatic leadership (Collinson, 2012; Kellerman, 2012).

The main objective of this article is to make a contribution to bringing these two fields together by looking at the practice of management in the Labour Party. Indeed, the subfield of organisational learning, which focusses on improving actual decision-making processes with a view to successfully adapting to changing environments, is of particular relevance to the study of party management. A characteristic of this study, therefore, is to be firmly grounded in empirical evidence ${ }^{1}$. The method adopted for this research is best understood as a form of grounded theory, where categories and concepts are drawn from the data. It is an approach which is empirically based but borrows a variety of thinking tools and concepts to identify patterns so as to make implicit belief systems explicit. Applied to New Labour party management, this method of enquiry helps uncover the main elements of a sweeping-

\footnotetext{
${ }^{1}$ This study is based on the empirical study of the changes undergone by the party and their manifestations at local, regional and national level, using ethnographic methods of data collection. As opposed to Lewis Minkin, whose seminal work on Labour party management (Minkin, 2014) has constituted a very useful source of information for this article, and who, as an adviser, enjoyed access to the party hierarchy and sought to have an influence on the evolution of party structures, I confined myself to roles which, like him, allowed me to collect the viewpoints and feelings of a wide range of actors, would give me access to behind the scene information not available to mere observers and would help me experience events as other party members did, but never with a view to exerting direct influence. More specifically, my focus was on the operational level. The different roles I assumed (observer, party member and campaigner, conference visitor or delegate, steward etc.) from the early 1990s to the mid-2000s allowed me to witness firsthand the culture clash between traditional members and the intake of new members as well as the tensions between local parties and regional and national party staff arising from the organisational reforms.
}

yet implicit-culture change designed to replace whatever was left of the traditional Labour conference delegate democracy with a new organisational culture sustained by a number of structural as well as behavioural changes. Therefore the aim of this article is to show the distinctiveness of New Labour's party management relative to previous forms, to reveal its mostly hidden mechanisms, and to highlight the short-term effects as well as the long-term consequences of the new managerial approach whose effects are still felt today. Seeking to understand how and why the New Labour party management generally seemed to negate its own objectives, this article opens with a definition of New Labour's brand of party management, then analyses its (often) unintended effects and impact on the organisation, leading to a more general assessment of the relationship between party management and organisational learning, so as to draw lessons from the New Labour experiment on change management in political parties.

\section{Defining New Labour's Brand of Leadership and Management}

Although party management has always existed and is consubstantial to any party, close analysis of the evolution of party organisation under New Labour shows that the development of a managerial system stands as one of Blair's main achievements and makes him historically different from previous Labour leaders (Minkin, 2014). It must be acknowledged from the outset that management in political parties is unavoidable and even useful. Like any other organisation, a party needs to coordinate its activities, to engineer organisational cohesion and generally to create an atmosphere of trust, so as to obtain the desired outcomes as defined by the leadership at a given point in time. If we take a historical perspective of the Labour party, we see that party management, even in its less palatable dimension of procedural fixing, has always been there, since tensions inevitably appear between the strategic and the operational levels, with party managers mediating between the two. What is meant by management here is not simply the administration of the party machine (even if this aspect also needs to be taken into account) but refers to "what the managers, past and present, themselves often talked of as 'management': the attempt to control problem-causing activities, issues and developments in order to ensure that outcomes were produced which the managers considered to be in the party's best interests" (Minkin, 2014, p. 1). In this perspective, management is a function conducted alongside other functions. What can be observed in the case of New Labour is that this dimension takes a new and distinctive turn, taking precedence over all other functions, in order to create cohesion and consensus within the party. The result is what Minkin describes as 
a "permanent revolution", or a "rolling coup", a succession of waves designed to take full control of the organisation. There is a tendency among academic and journalistic assessments of New Labour to question the very "newness" of the project and to seek to highlight elements of continuity, either with previous Labour experiences or with the Conservative administrations. I argue along with Minkin that, when it comes to management of the party, New Labour was fundamentally different and novel.

The analysis of New Labour's particular brand of management requires us to first explore the tension between management and leadership. There exists a well-established classic literature on the relationship between leadership and organisational structures. Max Weber (1922/2013) first pointed out the continuities of structure deriving from the bureaucratic form present within all large-scale organisations and Robert Michels (1915) highlighted, through his "Iron law of oligarchy", the bureaucratization of political parties. Angelo Panebianco (1988) then put forward the electoralprofessional party model characterized by the strengthening of the role of leadership through greater reliance on professionals and the use of new forms of communication techniques. More recently, Richard Katz and Peter Mair (1994) theorized the emergence of the highly centralized cartel party. On the other hand, the conventional wisdom in business theory about the respective roles of the leader and the manager, which states that the leader "does the right thing" and the manager "does things right", although crude, is quite relevant to political parties and constitutes a convenient starting point to an evaluation of New Labour's party management. In this view, the manager administers, has a short-range view and relies on control, while the leader innovates, has a long-range perspective and inspires trust. Even though leadership and management are very distinct concepts, in practice there is a natural overlap between the two. In the case of New Labour, it appears that they did more than overlap and that Blair's leadership was actually largely subsumed in management, a situation which Minkin defines as the "managerised" party (Minkin, 2014, p. 700).

A key dimension of the reforms is that they were based on a diagnosis of the party's weaknesses as resulting from tensions between party and government which had plagued previous Labour governments (the experience of the Wilson governments, repeatedly defeated at conference, stood out in particular). The New Labour project aimed to address this problem and was designed to bring party and leadership into alignment. Following the ideological adaptation brought about by the Policy Review conducted under Neil Kinnock, which, through a market research approach, aimed to identify the wishes of the electorate and adjust party policy accordingly, the views of the leadership were considered to be aligned with those of the voters. This meant ensuring that the local parties, the unions as well as dissident MPs could not get any traction. One key aspect of Blair's outlook-and one which clearly distinguishes him from previous reformist Labour leaders such as Kinnock-was also his lack of affinity with the Labour Party. In fact he appears to have generally regarded the party as the enemy, or at the very least an encumbrance and a source of embarrassment, rather than an asset and a source of leadership strength (Buller \& James, 2012, p. 548; Minkin, 2014). As a result, the whole New Labour management strategy rested on a negative evaluation of the party, of its previous leaders (of whom almost no mention was ever made) and of its organisational culture. Blair saw the party both as a vehicle for his political ambition and as an obstacle to be overcome. He recalls rather candidly in his autobiography that upon John Smith's death he had seen his opportunity to take hold of the Labour Party "like I suppose someone in business spots the next great opportunity, or an artist suddenly appreciates his own creative genius, or a coach or player knows that their moment for glory is about to come" (Blair, 2010, p. 59). At the same time he was telling his adviser Philip Gould "it's time we gave the party some electric shock treatment" (Gould, 1998, p. 218). The view was that the party needed to be corrected, its ideological baggage discarded and its traditional practices abandoned. Blair and his allies therefore thought it best to import a management culture which was alien to the party, resulting in a frontal and systematic attack on all the elements of the traditional Labour Party culture.

If we now try to characterize the New Labour variant of party management, a number of key features can be identified. ${ }^{2}$ A first feature is an ethics of delivery, more specifically an ethics of delivering to the leader rather than to the party, which lead to the extensive use of procedural fixes. Procedural tinkering is a constitutive part of management, which is outcomes rather than process oriented, and is to be expected. But this was taken to a new level with New Labour. Not only were rules and procedures seen as nothing more than time-wasting devices and scorned as "processology" (Minkin, 2014, p. 137), but there were used as "flexible instruments of power" (Minkin, 2014, p. 666) to deliver results regardless of the manner. A second major feature of New Labour's party management was

\footnotetext{
2 The elements presented in this section are based on Lewis Minkin's The Blair Supremacy (2014), private conversations with Minkin, as well as discussions during a workshop on Minkin's book organised by the PSA Labour Movements Group at the University of Leeds in October 2014, with contributions from Eric Shaw, Mark Wickham-Jones, Tim Heppell, Matt Beech, Lewis Minkin and myself. Some of these contributions have been published as a symposium in the Political Studies Review (see Avril, 2016).
} 
the increased politicization of national and regional party staff (which was part of the wider "professionalization" of the party). Party officials became partisan "party organisers" delivering to the leader and making up a praetorian guard around Blair. These elements were then underpinned by a culture change which is probably the most distinctive feature of New Labour. The modernisers around Blair-and Blair himselfdeveloped a specific attitude and behaviour, linked to their self-perception as an elite, a vanguard, imbued with a moral superiority which justified all the fixing. The New Labour people were steeped in a culture of being "bold" and unstoppable and relished the idea that they could get away with anything.

The elements of New Labour's change management strategy were hidden and dressed up in an official discourse of democratization. The reforms were said to aim at establishing a direct relationship between the leadership and the members, at doing away with what was dismissed as archaic routines (formal meetings were systematically described as excruciatingly boring and not an activity in which any sane member of the public would want to engage) so as to create a "vibrant", "healthy" party which would be attractive to new categories of members. In practice, this meant the removal of most decisions from the formal decisionmaking arena of the annual conference, through the creation of policy forums where discussions were supposed to bring about a more "consensual" approach. However, despite initial hopes (for a positive evaluation of the reforms, see Russell, 2005) the democratic quality of the new processes of policy making is very doubtful as procedures were designed so as to ensure the right results would emerge and dissenting voices struggled to make themselves heard (Heffernan, 2007, p. 156). The move towards direct democracy led to the erosion of the elective power of activists and the idea of increased membership participation did not entail increased membership influence (Avril, 2013). Generally, the new democratic processes presented in the 1998 Partnership in Power review document translated into mere consultation exercises with no real impact on policy formulation. Overall, New Labour's style of management can be defined as a form of a top-down, command-and-control "over-management", which translated into a pattern of self-reinforcing practices the effect of which was not only to produce counterproductive outcomes but more seriously to lead to a situation where the organisation found itself caught in a spiral of ever tightening control.

\section{The Unintended Effects of New Labour's Party Management}

We will now look at some of the ways the New Labour management reforms are seen to have failed to achieve their main goals and then assess the impact which some of the modernisers' errors of judgement had on the party. The counter-intuitive effects of change management have already been pointed out in the literature (notably Panebianco, 1988, p. 241). What is distinctive in the case of New Labour is that this specific party management approach appears to have been intrinsically self-defeating. Thus reforms which were designed to increase control often resulted, when implemented, in loss of control. The best-known cases, well documented and extensively commented upon in the media, are the messy handling, in 2000, of both the Livingstone mayoral candidacy in London and that of Rhodri Morgan's campaign to lead the Welsh Assembly, where the Labour leadership's efforts to manipulate the outcome generated outraged media comments and spectacularly backfired, since in both cases the candidates which the party leadership manoeuvred against went on to win. But even if the New Labour managers' "control freakery" and procedural fixing is a well-established fact, its extent and effects have been greatly underestimated.

A first unintended outcome was a result of the party leadership's belief that their views and those of the voters were the same (Avril, 2013; Minkin, 2014). The party (the trade unions and the Constituency Labour Parties) was seen as holding views which were harmful because they were thought to be at odds with how the voters felt. Those who held such views therefore needed to be contained. This strategy was particularly visible at the party conference where the New Labour managers used all the tricks in the book to ensure that there would be no damaging platform defeats. As I was able to observe, to avoid any coordinated rebellion, the principle of mandate was actively discouraged and inexperienced conference delegates were briefed by party staff to vote according to personal preferences, and not, as had been the practice, to reflect the majority views of their local party. This occasionally led to delegates from the same constituency voting against each other. Prior to crucial votes being taken, constituency delegates were often coaxed and/or intimidated through one-to-one encounters with ministers, and then through high-ranking party officers staring at them from a few feet away during the vote. The Leader's speech was now introduced by lengthy and loud warm ups of rousing pop songs and videos to the glory of the leader, with party organisers leading the clapping. But Minkin provides several little-known examples showing that the belief in an alignment between the leadership and the voters was incorrect since, in some cases, it was in fact the leadership which was at odds with public sentiment (Minkin, 2014, p. 599). With constituency delegates being sometimes persuaded to vote in ways which went counter to the wishes of the wider membership, the leadership in effect cut itself off from feedback from the floor.

The sustained efforts to control the grassroots were 
based on a misconception of local parties and members, who were seen, in keeping with the old Duverger model, as dangerous radicals who would thwart the modernisers' ambition to make the party more responsive to the voters. However, the rare empirical studies that have investigated the supposed ideological gap between Labour members and Labour voters (Seyd \& Whiteley, 2002) have shown it to be in fact a matter of degree rather than of a real divergence of opinions. The weakened organisational vitality (as seen through the decline in membership as well as in the low level of participation in internal elections) resulting from the disregard for the importance of local party activists was considered a risk worth taking. But the cost of alienating the party became apparent during the 2005 general election campaign when internal party discontent expressed itself mainly through diminished activism and with many local parties positioning their parliamentary candidates clearly in opposition to the New Labour line. Even more paradoxical for a party whose main objective was to win elections, one of the most immediate and most significant effects of the New Labour's party management, which worked hand in hand with management of the media, was the toxification of the party's image. As a string of events exposed the party leadership's willingness to bend the rules (starting with the Ecclestone scandal, then with the attempts to stop Ken Livingstone, and culminating with the controversial handling of the Commons over the Iraq war), New Labour soon found itself mired in a narrative of manipulation and deceit. As a result, from early on, public perceptions of New Labour were that it had a toxic influence on British political life (Avril, 2016).

Other arguments to support the view that the modernisers' achievements fell short of their objectives include the fact that many of the changes associated with New Labour (such as the renegotiation of the relationship with the trade unions, or the more voteroriented approach to policy-making) were initiated under Neil Kinnock and John Smith, well before Blair took over the party in 1994. Let us not forget either that Blair had not managed to get overwhelming support in 1994. In addition, Minkin's study shows that, overall, Blair never managed to establish a complete "supremacy" over the party and that he faced constant and often effective resistance from the PLP, the unions and the CLPs. In fact, according to Philip Cowley (2007), parliamentary rebellions were a direct result of Blair's autocratic style of leadership. Finally, even though Blair is commonly referred to in the literature as a "dominant" leader by virtue of his exceptional personal characteristics, his formidable status and resources as Prime Minister, and the very favourable conditions in which he started his premiership-even accounting for the often paralyzing tension with his internal challenger Gordon Brown-it is noticeable that he failed to make his position more secure and was eventually forced by a distrustful parliamentary party to step down at a time which was not of his own choosing. The gradual and inexorable depletion of Blair's capital, as highlighted by Bennister and Worthy (in press), can be accounted for to a large extent by his dysfunctional leadership and management methods. Overall the New Labour example shows that a command and control approach, which is supposed to entrench the leader's position, is likely to generate powerful countermovements.

New Labour was therefore clearly not the success story it has been described as. Not only is election victory obviously not the only criterion of success, but even in electoral terms the party's accomplishments need to be set against the fact that the New Labour governments presided over a period of rising concern about disaffected voters. The record level of abstention in the 2001 general election was such a shock that it prompted the setting up of the Audit of Political Engagement. In addition, Blair's leadership cannot be assessed in isolation from the project which was designed to sustain him in power. Party management under Brown retained the same features. In fact, the Blair/Brown duopoly was a constitutive part of the project and one of its main weaknesses. The new emphasis on consensus-building, on bringing party and government closer together, instead turned a pluralistic party into a highly factionalized one (Avril, 2016). In their unshakable belief that any public display of disagreement would be electorally damaging, the New Labour managers engaged in party management that was so heavy-handed that it eventually led to systemic failure. Awareness of these shortcomings was occasionally voiced by leading figures in the party, including key adviser Philip Gould who in 2000 acknowledged in a leaked memo that the New Labour brand had become "badly contaminated", notably by a perceived lack of integrity. "Almost every issue that has caused us difficulty has been anticipated" - he tellingly wrote- "but we have been powerless to turn foreknowledge into effective preventative action." (The Guardian, 2000). The puzzle, then, is to understand why the New Labour managers proved unable to change their ways.

\section{New Labour's Anti-Learning Practices}

There is an assumption that internal cohesion, in other words the harmony between the various groups which make up the organisation, is the condition for its durability. The Labour Party had patently suffered in the past from its image as a torn party. Shaw refers to this as a "debilitating civil war" which "impressed upon the public mind the image of an incessantly brawling and congenitally divided party" (Shaw, 1994, p. 166). However, even if disagreements are undeniably costly in electoral terms, one can also consider that too much consensus and the blandness of a "sanitized" party are 
also harmful (Seyd \& Whiteley, 1992, p. 207) since this type of party simply ends up putting the voters off as they can no longer distinguish between all the different parties. It also discourages activists, who lose any incentive to get mobilised and to campaign. Moreover, internal divisions may even help keep the party healthy, preventing it from ossifying, and counterbalancing the oligarchic tendencies identified by Michels. Internal contestation maintains the political organisation's dynamism and ability to innovate. The quest for consensus in the shaping of the New Labour party may therefore have been severely misguided from an organisational learning perspective.

Shaw expressed concern at the gradual centralisation of power in the New Labour Party, fearing "dwindling organisational vitality and ideological exhaustion" (Shaw, 1994, p. 166) and he underlined the necessity for an organisation wishing to avoid sclerosis to allow for the development within itself of units capable of autonomous action whose effect will be to provide an arena within which new ideas can be generated (Shaw, 2002). Instead, the New Labour approach reflected a strict implementation of the principle of collective responsibility (which Shaw compares, as Richard Crossman had done in his time, to Leninist democratic centralism), with minority opinions being ignored. This problem was clearly seen in the way the newly created policy forums functioned, where minority opinions often failed to even be recorded. Shaw concludes that "a malleable party is unlikely to be an energetic one", as shown by the mounting apathy within Labour ranks (Shaw, 2002). In an interview I conducted in 1995, Vladimir Derer, founder of the Campaign for Labour Party Democracy, expressed the view, echoed by many party members, that only political debate can keep activists, whom the leadership relies on to run the local parties and campaigns, interested. Participation in the political debate, which "wine and cheese evenings" could never replace, is an essential motivation for partisan engagement. Internal divisions and the possibility of expressing one's disapproval of the official line are a condition for organisational vitality. Therefore, if the risk of implosion is very real-as illustrated by the catastrophic party split of 1981 and the current disastrous public display of tensions between Corbyn and most Labour MPs - devitalisation may be just as dangerous.

Another danger is the loss of a critical mind. One of the most interesting revelations coming out of Minkin's observation of New Labour's party management is a mechanism which Minkin refers to as "wilful blindness" or "blinkered realism" (Minkin, 2014, p. 709), a wellknown phenomenon referred to in the field of organisational studies as "skilled unawareness" (Argyris, 2012). In this model, we find an in-group of people who overrate their ability to make the right decisions, who are in complete denial of any discrepancies, are not able to see the warning signs, and who tend to blame any failures on external factors. This behaviour results in a dysfunctional decision-making process reminiscent of Irving Janis's famous exposition of "groupthink" (Janis, 1972) which, he explains, is likely to result both in irrational decisions and dehumanizing actions directed against outgroups. Janis describes the symptoms indicative of groupthink: first, overestimation of the power and morality of the group (whereby excessive optimism and the unquestioned belief in the morality of the group causes members to ignore the consequences of their actions); second, closedmindedness (warnings which might challenge the group's assumptions are ignored and dissenters are stereotyped as weak, evil, biased or stupid); third, pressure towards uniformity (leading to the selfcensorship of ideas which deviate from the consensus, with members under pressure to conform).

The parallels with the behaviour and mind-set of New Labour managers are striking. Refusal to conform to the new orthodoxy exposed party members to accusations of disloyalty and the risk of being silenced at any cost. Left-winger Liz Davies, who served for two years on the party's National Executive Committee before resigning, illustrates in her book this pressure to conform and the harmfulness of such esprit de corps. She describes the nonsense pervading some of the NEC meetings where "cabinet members or Millbank staff would repeat the most implausible versions or explanations of events (the Guardian was a Tory paper, the election result was a disaster for Livingstone, rules existed even though no one had written them down) and nearly everyone around the table would nod in agreement" (Davies, 2001, p. 173). NEC members, concerned that they might lose other members' approval, carefully strove not to deviate from the consensus, opting to keep their doubts and worries to themselves for fear of being seen as disloyal, thus feeding the shared illusion of unanimity. This process, which executive management expert Karl Albrecht calls "learned incapacity" (Albrecht, 2003, pp. 17-38), condemns the organisation to certain failure, for when group members have literally "learned not to learn" errors no longer appear as such and the systematic response to emerging problems is the reckless decision to press on in the wrong direction.

The plebiscitary party model developed by Seyd and Whiteley stresses the same thwarted processes. This model, characterised by "a veneer of democracy disguising centralisation and control" (Seyd \& Whiteley, 2002, p. 176), is a threat to the party's chances of survival since this "empty" structure can no longer fulfil key traditional functions such as campaigning and recruitment. "The key problem" - they argue- "is that unaccountable power tends to make leaders stupid, out of touch and unwilling to do the hard work of building a rational case for policy initiatives" (Seyd \& Whiteley, 2002, p. 174). Although Minkin is critical of 
the plebiscitary model as applied to the Labour party, showing that early attempts initiated by Blair at conducting internal referendums (such as on the 1997 party manifesto) were considered internally as fiascos and were quickly abandoned (Minkin, 2014), both lines of analysis converge in stressing that orthodoxy and centralised control are a danger to the organisation which finds itself cut off from a vital source of innovation and more likely to make mistakes. Although it is obvious that an undisciplined party is almost guaranteed to lose elections, we can argue that the New Labour managers' exclusive concern for internal cohesion was even more harmful in the long run. This echoes Heppell's definition of toxic leaders as "those individuals whose leadership generates a serious and enduring negative, even poisonous, effect upon the individuals, families, organisations, communities and societies exposed to their methods" (Heppell, 2011, p. 243). In fact, "toxic"-or "destructive"-leadership is not only harmful to the organisation, since it subverts its structures and is negatively correlated to members' well-being and commitment (Schyns \& Schilling, 2013), but also selfdestructive. The way the New Labour leadership stifled all dissenting opinion, imposing a new orthodoxy throughout the organisation, turned the party into an exemplar of Goleman's classic "toxic organisation", an organisation which closed itself to new ideas for fear of having to question its own assumptions and where people stopped asking "how and why things [were] done" (Goleman, 2002, p. 195).

Some tenets of the field of innovation research, which emerged in the 1960s and rapidly expanded from the mid-1990s, also help shed light on some of New Labour's organisational shortcomings. In the socalled knowledge economy, innovation is universally regarded as vitally important to organisations of every nature. As the growing uncertainty of the working environment of businesses finds an echo in politics, where the effects of globalisation and technological change are also felt, parties are seeking new ways to respond to the challenge of a clientele that is increasingly difficult to attract and to retain. Clayton Christensen (2000) explains in his landmark book on innovation how traditional big businesses, which developed systems aiming at eliminating everything that the clients did not want, found themselves in a position of no longer being able to respond to the customers' expectations when these changed. Christensen thus identifies a "dilemma" which is that, in business, efficient managementmanagement focused on the short-term needs of customers and on improving the product-often turns out to be the very cause of eventual failure. This is a warning which the New Labour managers would have been well advised to heed when they devised a whole communication strategy aimed at "Middle England", a specific and narrow segment of the market deemed to be key. In his classic work on the rules of innovation,
James Utterback explains that once a new idea has been created, the future of the organisation will depend on whatever will be done with that new idea. He goes on to highlight the paradox of leaders closing ranks around an innovative idea so as to protect it, and concentrating on the product which the process has led to rather than on the process itself. "It is a great irony" - he writes-"that wisdom for many firms that derive current good fortune from radical innovations of the past lies in erecting barriers to these same types of innovations today" (Utterback, 1996, p. 224). This hostility to any further change which might threaten the new idea is clearly reflected in the Labour party modernisers' main concern to defend the New Labour "project", to unite the various sections of the party around it, rather than to create the conditions for new ideas to continue to emerge. Indeed, a key manifestation of the New Labour party management is the way the modernisers were trapped in a self-protective outlook whereby the problems resulting from Blair's leadership were never raised despite mounting evidence of poor decision-making. Blair himself simply could not question the assumptions on which his whole management of the party had been based and the New Labour managers around him generally found it difficult to accept that their approach may have produced adverse effects. Peter Mandelson, despite being one of Blair's main champions, describes him as someone who, once he had an idea, became "firm and persistent" about it, was "confident in his own overall judgement" and "expects the agreed plan to be carried out to the letter by those who work for him" (Mandelson \& Liddle, 1996, p. 53). In sum, what the field of innovation research tell us is that innovation is not so much about discarding the "old" as it is about harnessing the collective wisdom of the organisation's members.

A more appropriate organisational model, it is argued, is that of the "learning organisation", as originally defined by Peter Senge or Bob Garratt, ${ }^{3}$ where the learning potential of the organisation is considered as its only really long-lasting competitive advantage. This approach, also known as "action learning", which was pioneered by Reg Revans in the UK and Chris Argyris in the US in the 1970s and 1980s, and later popularized by Peter Senge, calls for a re-evaluation of the traditional managerial practices based on an obsolete taylorist and mechanistic conception of organisations. Action learning, also known as "double loop" learning, is a process of detection and correction of errors which

\footnotetext{
${ }^{3}$ We need to distinguish between two schools: on the one hand, "organisational learning", as theorised by Chris Argyris (see for example Argyris, 2004) which looks at the learning mechanisms within organisations, and, on the other hand, "the learning organisation" whose proponents focus essentially on advocating the adoption of new ways of functioning, as in the case of Peter Senge (1990) and Bob Garratt (2001).
} 
protects the organisation against modes of functioning that go against its long term interests. While single loop learning refers to corrections that do not question in-built theoretical assumptions, double loop learning challenges the mental models and allows for the governing norms and values to be adjusted (Argyris \& Schön, 1978). Crucially here, action learning is based on the idea that the key to improving performance does not lie with the abstract theories put forward by management experts, but with the practitioners themselves who learn from their own actions and experience (Boshyk \& Dilworth, 2010).

To assert its "newness", New Labour wanted a clean break from Labour's past, but what was swept away in the process was also the "accumulated wisdom of past experience" (Minkin, 2014, p. 143). New Labour's "anti-learning practices" (Minkin, 2014, p. 715) thus betrayed its inability to adopt the learning methodology required for the creation of new ideas. The effect of this inability to learn from mistakes and the systematic corruption of the party's internal democracy was to alienate both the members and the voters. In this sense, it is true to say that internal consensus and cohesion, as they manifested themselves in New Labour, constituted obstacles to innovation and therefore endangered the survival of the party. The antidote to this self-defeating management model lies with a leadership model which takes the well-being of members into account and which can generate an atmosphere of trust, where the aims of the party are not focused so much on explicit linear goals and more on the expressive functions of membership.

\section{Conclusion}

This analysis of the practice of party management under New Labour has shown the benefits of an approach drawing together the fields of political science and organisational studies to study the evolution of Labour Party power structures and processes under the leadership of Tony Blair. This approach is further bolstered by the fact that New Labour explicitly sought to emulate the private sector, with Blair trumpeting his admiration for management thinkers such as Charles Handy and Charles Leadbeater (who became his adviser). It is ironic that as Tony Blair became leader and as New Labour was swept into power, an entire wave of groundbreaking management books, developing the model of the learning organisation (Senge, 1990), offering new thinking on innovation - the books by Utterback (1996) and Christensen (2000) first came out in 1994 and 1997 respectively-and underlining the crucial importance of emotional intelligence in leadership (Goleman, 1998, 2002), came out in close succession, repudiating the managerial tenets which had dominated the 1980s and 1990s. Despite Blair supposedly seeking advice from high profile management thinkers, none of this new thinking seems to have filtered into New Labour's party management. At the time when New Labour was practicing self-censorship, in the business world emphasis was being placed on the production of new ideas as the best way of developing competitive advantage. Engaging fully with employees in strategy and delivery was now shown to be the key to achieving the organisation's objectives. The New Labour reforms, which aimed at increasing efficiency essentially through the suppression of any dissenting voice, were therefore out of step with this new thinking. In addition, Blair's model of the CEO being able to make decisions on the hoof without the encumbrance of procedures was anything but based on the practical realities of management in corporations. New Labour thus drew inspiration from thinking that was divorced from practice, on precepts which were being questioned within the private sector, and on a distorted vision of corporate life.

The rise and demise of the New Labour brand demonstrates that lack of respect for due process, emphasis on short-term success, and rule bending all have a short-term as well as long-term cost. The management processes, the rules and procedures an organisation follows, are more than mere technicalities. They affect the party's image and reputation in ways which reverberate beyond the boundaries of the organisation and which have an impact on the way the party engages with the voters. Rule twisting results in a loss of trust internally and externally, reinforcing voters' negative appraisals of political elites. The fact that Tony Blair is now widely disliked, perceived as he is as a "celebrity'" bent on raking the money in, gives an indication of this cost. But the damage goes much further since the whole organisation became tainted. The Labour Party was left discredited and disconnected, with weakened ties to its "natural" constituency. Therefore what this article has shown is how this kind of "dominant" leadership, which can be said to be strong in a command and control sense, achieves results that fall considerably short of what was sought (Bennister \& Worthy, in press; Brown, 2014) and is even largely counterproductive.

The post-Blair Labour Party, where lack of charisma in leaders has become a virtue, bears the hallmarks of this legacy, in a way which recalls the predicaments of the post-Thatcher Conservative Party. Indeed, the toxic/heroic ambivalence outlined by Lipman-Bluman (2004) is particularly relevant to the analysis of the poisonous legacy of charismatic leaders such as Blair. An organisational culture which erects the loyalty and compliance of team members as its cardinal values, and where leaders are encouraged to believe in their own narrative that all is well despite evidence to the contrary (Collinson, 2012), fatally curtails a party's ability to learn and to evolve. Contrary to Minkin's hopeful statement that, with the end of New Labour, the damage has largely been undone, descriptions of $\mathrm{Ed}$ 
Miliband's excessive reliance on a very small circle of trusted allies and of his tendency to interpret any criticism as a sign of disloyalty (Wintour, 2015) seem to confirm that the organisational reflexes acquired in the New Labour years are very difficult to shake off (Heffernan, 2007). This analysis of the legacy of Blair's brand of party management has therefore underlined the long-term impact of this organisational transformation on the way the Labour Party has since continued to (dys)function as an organisation, with wider consequences for British politics. The line of inquiry presented in this article thus opens many avenues for further research on the leadership and management of political organisations.

\section{Acknowledgments}

I would like to thank my colleagues of the Political Leadership group of the Political Studies Association who gave me the opportunity to present a first version of this article as a paper, and in particular group convenor Mark Bennister for encouraging me to submit an extended written version. I also thank my university, the Sorbonne Nouvelle, for giving me the financial backing necessary for taking part in the 2015 PSA Annual Conference as well as my colleague Professor Richard Davis for proofreading the final version.

\section{Conflict of Interests}

The author declares no conflict of interests.

\section{References}

Albrecht, K. (2003). The power of minds at work. Organizational intelligence in action. New York, NY: Amacom.

Argyris, C., \& Schön, D. (1978). Organizational learning: A theory of action perspective. Boston, MA: AddisonWesley.

Argyris, C. (2004). Reasons and rationalizations: The limits of organizational knowledge. Oxford: Oxford University Press.

Argyris, C. (2012). Organizational traps: Leadership, culture, organizational design. Oxford: Oxford University Press.

Avril, E. (2013). The evolution of decision-making in the British Labour Party: From grassroots to netroots? In E. Avril \& C. Zumello (Eds.), New technologies, organizational change and governance (pp. 102-116). Basingstoke, UK: Palgrave Macmillan.

Avril, E. (2016). 'Wilful blindness': Effects and perceptions of New Labour's party management. Political Studies Review, 14(2), 163-174.

Avril, E., \& Zumello, C. (2013). Towards organizational democracy? Convergence and divergence in models of economic and political governance. In E. Avril \& C.
Zumello (Eds.), New technologies, organizational change and governance (pp. 1-20). Basingstoke, UK: Palgrave Macmillan.

Bennister, M., \& Worthy, B. (in press). Limits to dominance? Comparing the leadership capital of Margaret Thatcher and Tony Blair. In M. Bennister, P. 't Hart, \& B. Worthy (Eds.), The politics of leadership capital: Comparing the dynamics of leadership. Oxford: Oxford University Press.

Blair, T. (2010). A journey. My political life. London, UK: Hutchinson.

Boshyk, Y., \& Dilworth, R. L. (Eds.). (2010). Action learning: History and evolution. Basingstoke, UK: Palgrave Macmillan.

Brown, A. (2014). The myth of the strong leader. London: Bodley Head Adults.

Buller, J., \& James, T. (2012). Statecraft and the assessment of national political leaders: The case of New Labour and Tony Blair. British Journal of Politics and International Relations, 14(4), 534-555.

Christensen, C. (2000). The innovator's dilemma (2nd ed.). London: HarperBusiness Essentials.

Collinson, D. (2012). Prozac leadership and the limits of positive thinking. Leadership, 8(2), 87-107.

Cowley, P (2007). Parliament. In A. Seldon (Ed.), Blair's Britain 1997-2007 (pp. 16-34). Cambridge: Cambridge University Press.

Davies, L. (2001). Through the looking glass. A dissenter inside New Labour. London: Verso.

Garratt, B. (2001). The learning organization. Developing democracy at work. London: HarperCollinsBusiness.

Goleman, D. (1998). Working with emotional intelligence. London: Bloomsbury.

Goleman, D. (2002). The new leaders. Transforming the art of leadership into the science of results. Boston, MA: Little, Brown and Company.

Gould, P. (1998). The unfinished revolution. How the modernisers saved the Labour Party. London: Little, Brown and Company.

Heffernan, R. (2007). Tony Blair as Labour Party leader. In A. Seldon (Ed.), Blair's Britain, 1997-2007 (pp. 143163). Cambridge, UK: Cambridge University Press.

Heppell, T. (2011). Toxic leadership: Applying the Lipman-Blumen model to political leadership. Representation, 47(3), 241-249.

Janis, I. (1972). Victims of groupthink: A psychological study of foreign policy decisions and fiascoes. Boston, MA: Houghton Mifflin.

Katz, R. S., \& Mair, P. (1994). How parties organize: Change and adaptation in party organizations in Western democracies. London: Sage.

Kellerman, B. (2012). The end of leadership. New York, NY: Harper Business.

LaPalombara, J. (2003). Power and politics in organizations: Public and private sector comparisons. In M. Dierkes, A. Berthoin Antal, J. Child, \& I. Nonaka (Eds.), Handbook of organizational learning and 
knowledge (pp. 557-581). Oxford: Oxford University Press.

Lipman-Blumen, J. (2004). The allure of toxic leaders: Why we follow destructive bosses and corrupt politicians-and how we can survive them. Oxford: Oxford University Press.

Mandelson, P., \& Liddle, R. (1996). The Blair revolution. Can New Labour deliver? London: Faber \& Faber.

McAnulla S. (2011). Post-political poisons? Evaluating the 'toxic' dimensions of Tony Blair's leadership. Representation, 47(3), 251-263.

Michels, R. (1915). Political parties. A sociological study of the oligarchical tendencies of modern democracy. New York, NY: Free Press.

Minkin, L. (2014). The Blair supremacy. A study in the politics of Labour's Party management. Manchester: Manchester University Press.

Padilla, A., Hogan, R., \& Kaiser, R. B. (2007). The toxic triangle: Destructive leaders, susceptible followers, and conducive environments. The Leadership Quarterly, 18, 176-194.

Panebianco, A. (1988). Political parties, organization and power. Cambridge: Cambridge University Press.

Russell, M. (2005). Building New Labour. The politics of party organisation. Basingstoke, UK: Palgrave Macmillan.

Schyns, B., \& Schilling, J. (2013). How bad are the effects of bad leaders? A meta-analysis of destructive leadership and its outcomes. The Leadership Quarterly, 24, 138-158.
Senge, P. (1990). The fitfh discipline. The art and practice of the learning organization. New York, NY: Random House.

Seyd, P., \& Whiteley, P. (1992). Labour's grassroots. The politics of party membership. Oxford: Clarendon Press.

Seyd, P., \& Whiteley, P. (2002). New Labour's grassroots. The transformation of the Labour Party membership. Basingstoke, UK: Palgrave Macmillan.

Shaw, E. (1994). Conflict and cohesion in the British Labour Party. In D. Bell \& E. Shaw (Eds.), Conflict and cohesion in Western European social democratic parties (pp. 151-167). London: Pinter Publishers.

Shaw, E. (2002). New Labour in Britain: New democratic centralism? West European Politics, 25(3), 147-170.

The Guardian (2000, July 19). Full text: Philip Gould's leaked memo. The Guardian. Retrieved from http://www.theguardian.com/politics/2000/jul/19/la bour.labour1997to99

Utterback, J. (1996). Mastering the dynamics of innovation (2nd ed.). Boston, MA: Harvard Business School Press.

Weber, M. (2013). Economy and society. Two volume set first edition. Berkeley, CA: University of California Press. (Original work published 1922).

Wintour, P. (2015, June 3). The undoing of Ed Milibandand how Labour lost the election. The Guardian. Retrieved from http://www.theguardian.com/politics/ 2015/jun/03/undoing-of-ed-miliband-and-howlabour-lost-election

\section{About the Author}

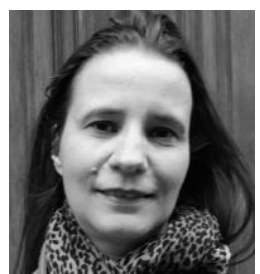

Emmanuelle Avril is Professor of British Politics and Society at the Sorbonne Nouvelle University in Paris. Her specialist subject is intra-party democracy, organizational change and mobilisation within the British Labour Party, which has come to include a study of the impact of new technologies on party membership and activism. Her publications include New Technologies, Organizational Change and Governance (Palgrave Macmillan, 2013, co-edited) and Democracy, Participation and Contestation. Civil Society, Governance and the Future of Liberal Democracy (Routledge, 2014, co-edited). 